\title{
Gender pairings in EFL child task-based interaction
}

\author{
Maria Martinez-Adrián \\ Department of English, German and Translation and Interpretation Studies \\ University of the Basque Country UPV/EHU \\ maria.martineza@ehu.eus \\ Maria Juncal Gutiérrez-Mangado \\ Department of English, German and Translation and Interpretation Studies \\ University of the Basque Country UPV/EHU \\ junkal.gutierrez@ehu.eus
}

\begin{abstract}
Few studies have tackled gender differences in second language (L2) interaction, and particularly, the effect of gender pairings on learning opportunities operationalized as Language Related Episodes (LREs) has been scarcely looked into (see Azkarai, 2015b; Azkarai \& García-Mayo, 2012; Ross-Feldman, 2005, 2007). Additionally, these studies have targeted adult L2 learners and to our knowledge, no studies so far have been conducted with children. This paper will try to fill these gaps by analysing the effect of gender pairings on the occurrence, nature and resolution of LREs in a storytelling task performed by 10-12-year-old children. More specifically, it explores whether there are any differences between same-gender and gender-mismatched dyads, and between same-gender dyads (male-male vs female-female). Results show that type of pairing affects LRE production and resolution as more LREs were initiated and resolved in matched-gender dyads than in mixed-gender dyads. However, gender-pairing did not influence the outcome of the resolution, as a still low rate of targetlikeness was obtained in mixed-and matched-gender dyads. Additionally, no statistically significant differences were obtained between same-gender dyads, but female-female dyads were found to be more concerned with getting the message across and oriented to higher accuracy in the resolutions of meaning-related episodes.
\end{abstract}

Keywords: gender pairings; young learners; language related episodes; task-based interaction; English as a foreign language. 


\section{Resumen}

Pocos han sido los estudios que han abordado las diferencias de género durante la interacción en una segunda lengua (L2), y particularmente, el efecto de los emparejamientos según el género de los aprendices en la producción de Episodios Relacionados con el Lenguaje (ERLs) ha sido poco investigado (véase Azkarai, 2015b; Azkarai y García Mayo, 2012; Ross-Feldman, 2005, 2007). Del mismo modo, dichas investigaciones han examinado aprendices adultos, y no parecen existir investigaciones con niños. Este trabajo analiza el efecto de los emparejamientos según el género de sus miembros en la ocurrencia, naturaleza y resolución de ERLs surgidos durante la narración oral de una historia por parte de niños de 10 a 12 años. Concretamente, explora si existen diferencias entre parejas de mismo y distinto género, y entre parejas de mismo género (niño-niño vs. niña-niña). Los resultados demuestran que el tipo de emparejamiento afecta a la producción y resolución de ERLs ya que un mayor número de ERLs fueron iniciados y resueltos en parejas del mismo género frente a parejas de distinto género. Sin embargo, el tipo de emparejamiento (mismo vs. distinto género) no tuvo repercusión a nivel de episodios resueltos de forma correcta. Por otro lado, la comparación entre parejas del mismo género no conllevó diferencias significativas, aunque el análisis descriptivo sí indicó que las parejas formadas únicamente por chicas parecían estar más implicadas en transmitir el mensaje y más orientadas hacia una resolución correcta de los episodios relacionados con el léxico.

Palabras clave: emparejamientos por género; jóvenes aprendices; episodios relacionados con el lenguaje; interacción durante la realización de tareas; inglés como lengua extranjera.

\section{Introduction}

The study of the effect of gender on second language (L2) performance has been approached from two different social perspectives. On the one hand, studies examining gender attitudes and learning outcomes have claimed that language skills in the case of females develop quicker than in males. In addition, females show a higher inclination to study foreign languages and have more positive attitudes and greater motivation towards languages (Pavlenko \& Piller, 2008; Spolsky, 1989; Sunderland, 2000). On the other hand, another strand of studies within the Interactionist framework, though more limited, has explored the effect of dyad type on task-based interaction. In this respect, mixed results in terms of amount of negotiation have been obtained in English as a second language (ESL) and English as foreign language (EFL) settings (i.e. Azkarai \& Imaz Agirre, 2017; Oliver, 2002; Shehadeh, 1994, 1999). Also within the Interactionist framework, other studies have explored the impact of collaborative 
tasks on attention to form operationalized as Language Related Episodes (LREs). This construct has been defined as any part of the dialogue in which students talk about the language they are producing, question their language use, or other- or self-correct' (Swain, 1998: 70). However, to the knowledge of the authors, this line of research has received scant attention in the literature and no studies have been conducted with young learners. Studies carried out with adult learners on LRE production have reported the inexistence of differences between mixed and matched-gender pairings except for resolution. This line of research is fully justified in the case of young learners if we consider their different engagement in the language learning process from adult learners (Oliver \& Azkarai, 2017). The analysis of the impact of gender on the production of LREs during child task-based interaction may shed more light on the most efficient learner pairings and may contribute to maximize the learning potential of collaborative tasks for attention to form. Exploiting the resources at hand seems to be even more important in EFL contexts, also considered low input settings (Pinter, 2011) where learners cannot benefit from the large amounts of exposure offered in ESL settings.

The paper is organized as follows. Section 2 provides an overview of empirical findings related to the effect of gender on interaction as well as on language learning opportunities (LREs). The study is described in section 3. Results are subsequently shown and discussed in sections 4 and 5, respectively. Section 6 concludes the paper.

\section{Literature review}

\subsection{Gender and interaction}

The difference in communicative patterns observed in males and females during first language (L1) interaction has its origin in the socialization process during childhood (Azkarai, 2013). Children spend large amounts of time playing and interacting with same-gender friends (Maltz \& Borker, 1982; Tannen, 1994). This entails that boys and girls have different experiences and learn many skills, competencies, and interests in their interactions with same-sex peers (Hanish \& Fabes, 2014).

Sex segregation emerges early in life and by preschool, about half of children's interactions are with same-sex peers (Fabes, Martin, \& Hanish, 2003), and it persists through preadolescence and adulthood (Mehta \& Strough, 2009, 2010). It has important consequences for the development of communication skills. In particular, males and females develop different ways to express themselves (Maltz \& Borker, 1982). For example, research has shown how females in matched-gender dyads tend 
to talk more overall and discuss fewer topics than males who discuss many topics briefly. Additionally, males' discussions are more abstract than females' (Tannen, 1990). In mixed-gender dyads, males have been reported to discuss a wider range of topics than in male-only groups (Aries, 1976), and have also been found to have more opportunities to participate and control conversations than females (see Bohn \& Stutman, 1983; West \& García, 1988; West \& Zimmerman, 1983; Zimmerman \& West, 1975). These behaviours observed in males and females might have an impact on L2 learning opportunities during task-based interaction.

In $\mathrm{L} 2$ acquisition, gender has received limited attention within the interactional approach (Long, 1996) and mixed findings have been obtained, which could be ascribed to the interaction between cultural norms and gender. As discussed by Shehadeh (1999), it is more acceptable in some cultures and subcultures than in others for men and women to communicate freely and casually with each other at work and in social situations (p. 260). As a result, the different cultures of talk imposed on males and females that could vary across contexts (see Pavlenko, 2001 in this respect) should not be overlooked and research should place gender differences within specific contexts (Gu, 2013). Studies conducted in ESL and EFL contexts with adults and children have specifically tested the effect of dyad-type on task-based interaction. Some of these studies have yielded differences between mixed and same-gender dyads, while other investigations have not found differences between dyad-types. In the case of studies conducted with adults in ESL contexts, Shehadeh (1994) in an investigation with L2 learners with a variety of L1s (i.e. Afrikaans, Arabic, Bengali, Cantonese, Farsi, French, Greek, Italian, Korean, Mandarin, Portuguese, Serbo-Croat and Spanish) reported the existence of more opportunities for males to produce comprehensible output and to request clarifications in mixed-gender dyads, while females appeared to have more opportunities to produce comprehensible output in matched-gender dyads. In Gass and Varonis (1986) more negotiations in the case of L1 Japanese learners of L2 English occurred in mixed-gender dyads than in matched-gender dyads. Other studies conducted with L1 Japanese adult learners of L2 English such as Pica et al. (1991) have not found significant differences between types of dyads. As for children, to our knowledge, only Oliver (2002) has focused on gender and interaction in ESL settings, where she reported non-significant differences between male-male and female-female dyads.

In EFL settings, particularly in the Spanish context in which the present study was conducted, more research also exists with adults than with children but the findings have also been mixed. Adult females negotiate more in matched-gender dyads than in mixed-gender settings (Alcón, 1994) and tend to resort to their L1 more than males (Azkarai, 2015a). In mixed-gender dyads, males have been reported to interrupt and talk more frequently and introduce a greater number and wider range of topics (Alcón, 
1994). In other studies with adults, such as Alcón and Codina (1996), overall gender did not affect negotiation but some task effects were found when comparing femalefemale dyads and mixed-gender dyads, as also reported in Birjandi and Tabatabaei (2010). In the information-gap task administered, females negotiated more than males, while no differences existed in the discussion task they performed. As in the ESL context, little research has also been conducted with children in EFL settings along these lines (Azkarai \& Imaz Agirre, 2017) and a call has been made by several authors for research with children as it could have implications aimed at maximizing contact hours with learners. Knowing about the impact of gender on interaction might help teachers to organize activities that take advantage of the most convenient pairings. In Azkarai and Imaz Agirre (2017) with 3rd and 4th year primary-school learners, younger learners were found to negotiate more in same-gender dyads, while older learners did so in mixed-gender dyads.

\subsection{Gender and LREs}

Other studies within the interactional framework have specifically tested the effect of gender on the production of LREs, but are more limited in number (Azkarai, 2015b; Azkarai \& García Mayo, 2012; Ross-Feldman, 2005, 2007). As stated by RossFeldman (2007: 57), any effect of gender on the incidence and resolution of LREs might differentially influence the language learning opportunities available to male and female learners as a result of engaging in interaction. Ross-Feldman $(2005,2007)$ examined the incidence and resolution of LREs of 32 male and 32 female ESL learners while working in mixed and matched-gender dyads in three different tasks (picture differences, picture placement and picture story task). Each participant interacted in both mixed and matched-gender dyads. The analysis consisted in the comparison of different dyad types, comparison of males to females in mixed-gender dyads and the comparison of the interaction of the same learner in matched and mixed-gender dyads. The results showed that as for incidence, whether participants interacted in mixed or matched-gender dyads did not significantly influence the production of LREs. However, in terms of resolution, in mixed-gender dyads, LREs initiated by males were resolved more often than LREs initiated by females. Similarly, when comparing the interaction of the same learner in mixed-and matched-gender dyads, LREs initiated by males were resolved more often in mixed-gender dyads than in matched-gender dyads, and LREs initiated by females were resolved more often in matched-gender than in mixed-gender dyads. In the light of the results shown in this study, Ross-Feldman concludes that males have more opportunities to learn the target language (TL) when working in mixed-gender dyads, while females have more opportunities in matchedgender dyads, results which have also been supported by Aries (1976) and Holmes (1994) and also by research in education (Sadker \& Sadker, 1994). 
More recently, Azkarai \& García Mayo (2012), and Azkarai (2015b) tested the effect of dyad-type on the production of LREs by EFL learners along the same lines as Ross-Feldman $(2005,2007)$. In particular, Azkarai (2015b) which included a greater number of participants than Azkarai \& García Mayo (2012), examined 22 males and 22 females while completing four different tasks. They worked first in matched-gender dyads and then in mixed-gender dyads. When comparing males and females in terms of number, nature (meaning and form), and outcome of LREs, the analysis of the results did not yield statistically significant differences. These findings support Ross-Feldman (2005, 2007) and Azkarai \& García Mayo (2012) when examining incidence and nature of LREs. However, they contrast with Ross-Feldman $(2005,2007)$ in terms of outcome, as in her study LREs initiated by males were resolved significantly more often than those initiated by females. The different social context in Ross-Feldman $(2005,2007)$ and Azkarai (2015b) might be the underlying reason for these differences. Namely, socialization patterns in South America, where the study by Ross-Feldman (2005, 2007) was conducted, are different from the ones in Europe, where the investigations by Azkarai \& García Mayo (2012) and Azkarai (2015b) were carried out. Azkarai (2015b) also focused on the possible differences in LREs initiated by males and females depending on the gender of the interlocutor. No differences were found in nature and occurrence of LREs when females worked in mixed or matched-gender dyads, but differences emerged in the case of outcome, as females resolved more LREs when working with males. Similarly, no differences in incidence and nature of LREs were obtained when males worked either in mixed and matched-gender pairings. However, males ignored more LREs in matched-gender dyads. These results also contrast with Ross-Feldman $(2005,2007)$, as in her study working in mixed dyads seemed to favour male learners while working in matched-gender dyads seemed to be more profitable for females. In conclusion, males and females focused similarly on meaning and form in same-gender and mixed-gender dyads. But in terms of resolution, males and females seem to benefit more when working in mixed-gender pairings.

As the dearth of studies described above suggests, the impact of type of pairing on the production, nature and resolution of LREs has been scarcely looked into. In particular, to our knowledge, just four studies have explored males' and females' behaviour working in mixed and matched gender dyads (see Azkarai, 2015b; Azkarai \& García-Mayo, 2012; Ross-Feldman, 2005, 2007). In addition, all these studies have targeted adult learners, and no investigations along these lines have been conducted with children. In this respect, a call has been made for more research on young L2 learners given the specificity of their language learning approach and their peer exchanges in this population (Muñoz, 2007; as cited in Plavadevall Ballester \& Vraciu, 2020). This article will try to fill these gaps by analyzing the oral interaction of young Spanish EFL learners on the basis of their gender and the language learning 
opportunities (operationalized as LREs) available to them during task-based interaction. In particular, this paper aims to study gender differences in the occurrence, nature and outcome of LREs on the basis of Azkarai (2015b). More specifically, whether there are any differences between same-gender and gender-mismatched dyads, and between same-gender dyads (male-male vs female-female).

\section{The Study}

The present study is part of a bigger project on task-modality effects among young learners. In particular, this study investigates the effect of gender pairings on the production of LREs by 10-12 year old children in a primary school from the Basque Country (Spain) with the aim of answering the following research questions:

(1) Are there any differences in terms of number, types and outcome of LREs among different types of gender-pairings?

1.a. Are there any differences between same-gender and mixed-gender dyads?

1.b. Are there any differences between male-male and female-female dyads?

(2) What are the more common types of LREs (nature and outcome) in each dyad group?

\subsection{Participants}

The participants in the study were 56 (19 females, 37 males) child EFL learners, aged 10-12, from two intact classes ${ }^{1}$ in the $5^{\text {th }}$ year (14 males, 8 females) and three in the 6th year (23 males, 11 females) of primary education in the Basque Autonomous Community in Spain, a European country offering balanced opportunities for males and females to interact (Azkarai, 2015b). The participants were attending the educational model $\mathrm{D}$, by which the vast majority of instruction takes place in Basque (the minority language of the area in which these learners live). Spanish Language and its Literature is taught in Spanish, and English as a language subject and content subjects such as science, arts and crafts or physical education are taught in English. This model was originally created as a language maintenance programme for native speakers of Basque but nowadays, this programme includes a high number of L1

1 In this project we decided to preserve 'ecological validity' (Van Lier, 1988) by gathering data from intact groups instead of a tight control of extraneous variables as in true experiments. In this respect, this study could be best described as exploratory. The findings obtained will be concurrently validated in further investigations with a more balanced sample. 
Spanish students who can achieve a level of functional competence in Basque alongside the 'usual' level of knowledge of the L1 (Zalbide \& Cenoz, 2008: 9). Thus, participants in this model are considered Basque-Spanish bilinguals who learn their third language (L3) chronologically speaking, as a foreign language (Cenoz, 2009).

They started learning L3 English as a school subject at around age 4 and since Grade 3 they have been enrolled in a CLIL programme in which English is used as a language of instruction for the aforementioned content subjects. At the time of data collection, they were receiving 3 hours of EFL instruction and 2 to 4 hours a week of CLIL instruction.

The fifth grade children had accumulated approximately 777 hours of instruction in English, and the sixth grade children 962 hours. Before data collection, the children were administered a linguistic background questionnaire and an English placement test (KET) whose results indicated that participants could be considered beginners (A1-A2) ${ }^{2}$. Participant main characteristics together with their proficiency scores are shown in Table 1.

Table 1. Participants' characteristics

\begin{tabular}{|c|c|c|c|c|}
\hline & \multicolumn{2}{|c|}{ LH5 } & \multicolumn{2}{|c|}{ LH6 } \\
\hline & Females & Males & Females & Males \\
\hline Mean Age at testing & $\begin{array}{c}9.5 \\
(\mathrm{SD}: 0.53)\end{array}$ & $\begin{array}{c}9.92 \\
(\mathrm{SD}: 0.26)\end{array}$ & $\begin{array}{c}11 \\
(\mathrm{SD}: 0.77)\end{array}$ & $\begin{array}{c}10.92 \\
(\mathrm{SD}: 0.57)\end{array}$ \\
\hline Mean AoA English & $\begin{array}{c}4.12 \\
\text { (SD: } 0.83)\end{array}$ & $\begin{array}{c}4.07 \\
(\mathrm{SD}: 1.68)\end{array}$ & $\begin{array}{c}4.81 \\
\text { (SD: } 1.16)\end{array}$ & $\begin{array}{c}4.88 \\
(\mathrm{SD}: 1.78)\end{array}$ \\
\hline $\begin{array}{l}\text { Test score } \\
\text { (Max. score in the test }=85 \text { ) }\end{array}$ & $\begin{array}{c}24.62 \\
(\mathrm{SD}: 6.45) \\
\end{array}$ & $\begin{array}{c}27.21 \\
\text { (SD: } 11.44)\end{array}$ & $\begin{array}{c}46.63 \\
\text { (SD: } 14.41)\end{array}$ & $\begin{aligned} & 42.96 \\
&\text { (SD: } 18.20) \\
&\end{aligned}$ \\
\hline
\end{tabular}

Note: $\mathrm{SD}=$ standard deviation; $\mathrm{AoA}=$ age of acquisition.

The children were paired into 28 dyads to perform the collaborative tasks administered in the project. Even if all the participants in the project were considered beginners as their scores fell in the range A1-A2, they were paired with children from the same grade and matched in same-proficiency dyads. This yielded the following gender-pairings: 7 dyads were gender mismatched ( 2 from the $5^{\text {th }}$ year and 5 form the $6^{\text {th }}$ year); 6 were female-female (FF) dyads ( 3 from the $5^{\text {th }}$ year and 3 from the $6^{\text {th }}$ year) and 15 were male-male (MM) dyads ( 6 from the $5^{\text {th }}$ year and 9 from the $6^{\text {th }}$ year). As another safeguard to control for proficiency measures, a Mann-Whitney U Test was computed

2 Basic users according to the Common European Framework of Reference for languages http://www. coe.int/t/dg4/linguistic/Source/Framework_en.pdf 
to compare male and female participants which revealed the inexistence of statistically significant differences in terms of proficiency $(Z=-0.666$; $p$-value $=0.506)$. Thus, any potential gender differences during task-based interaction cannot be ascribed to their distinct proficiency level.

\subsection{Materials and procedure}

The task described in the present paper is part of a wider project aimed at investigating collaborative tasks (speaking and speaking ${ }^{+}$writing tasks) in primaryschool children. In particular, this project is making a valuable contribution to the still limited study of young learners in foreign language contexts by investigating taskmodality effects attested in previous research with adults (see García Mayo \& Azkarai, 2016) ${ }^{3}$. Children's uniqueness in their engagement in the learning process clearly reinforces the specificity of L2 research with this population (Mackey \& Gass, 2005; as cited in Oliver \& Azkarai, 2017). Thus, in this project similar tasks to the ones employed with adults have been designed so as to investigate whether similar results would be obtained and whether any potential adaptations should be included so as to maximize children's opportunities for learning (García Mayo, 2017).

For the task reported here (speaking task), each pair was video-taped while ordering a set of six pictures (see Appendix 1) before orally narrating the events depicted in them in story mode. This story was chosen from an appropriate level English book, Sparks 1 (House \& Scott, 2009), with the teachers' approval and it was pilot-tested with similar age children prior to its administration.

Tasks where pictures have to be ordered before narrating the story depicted have been widely used in ESL and EFL research (García Mayo \& Lázaro Ibarrola, 2015; García Mayo \& Hidalgo Gordo, 2017; Lázaro Ibarrola \& Azpilicueta Martínez, 2015; Martínez-Adrián, 2020; Pica, Kang, \& Sauro, 2006; Pica et al. 1993) because they create real opportunities for students to interact with each other in order to agree on the order of the pictures and the possible story which they depict. This type of oral tasks are considered more immediate tasks, with very little planning and editing time, and their primary focus is meaning (Payant \& Kim, 2019). In contrast, tasks that combine speaking and writing modalities seem to demand higher levels of accuracy because of the extra processing time learners have to reflect on their production

\footnotetext{
3 In the first set of investigations conducted within the project (Martínez-Adrián \& Gallardo-delPuerto, forthcoming; Gallardo-del-Puerto \& Martínez-Adrián, in press; Gutiérrez-Mangado \& Basterrechea, forthcoming) and so as to obtain an overall picture of task-modality effects, we have compared different tasks and modalities, leaving the interface between modality and other grouping variables for further research.
} 
(i.e. Adams \& Ross-Feldman, 2008; Azkarai \& García Mayo, 2015; García Mayo \& Azkarai, 2016; Niu, 2009; Payant \& Kim, 2019). However, these studies that have compared speaking tasks to speaking+writing tasks have not controlled for the level of accuracy that both tasks demand. Thus, in order to solve the limitation of previous research and taking into account that the framing of the task could overrule the inherent focus of the task (Philp, Walter, \& Basturkmen, 2010), in the present project, instructions were kept constant by asking learners to attend to accuracy in the tasks administered. More specifically, participants performing the speaking task were asked to pay special attention to the way they told the story in that it had to make sense but also be linguistically accurate.

The task was carried out in a quiet room with the presence of the investigator, who explained the task and gave precise instructions in the TL English as to how to carry it out. The children were asked to act naturally and were also informed that they could seek out each other's help (but not the assistant's) in case of difficulties with vocabulary.

\subsection{Data codification and analysis}

Participants' oral interactions were transcribed verbatim and coded in CHILDES (MacWhinney, 2000) format. The transcriptions were analysed in order to identify all LREs. LREs were classified on the basis of their nature (meaning vs. form) and outcome (resolved vs. unresolved). Resolved LREs were further categorized as targetlike or non-target-like (Azkarai, 2015b; Ross-Feldman, 2005, 2007). They were first coded by one of the researchers and then checked by another one. Mismatches between both researchers were resolved through discussion.

LREs were classified as meaning-related when the interaction involved the meaning or use of a word and form-related when they related to the grammatical form (phonology, morphology, syntax, spelling or preposition) of a word or sentence. LREs were further coded as resolved when a solution was provided to the issue raised in the LRE or unresolved when proceeded with the task without finding a solution (1). Solved LREs were further classified as target-like, when the solution suggested by the interlocutor's feedback was correct (2) or as non-target-like when the proposed solution was incorrect (3).

(1) Meaning focused; unresolved

$1 \mathrm{HL}$ eeeh, I have for ... my sister and ... af eh ... ¿cómo se dice coser? [how do you say to sew?]

2 AR I don't know. 
(2) Form focused; solved; target-like

1 AC eh... once upon a time eh ... eh ... there is two friends and she eh and .... and.

2 MG they are.

(3) Meaning focused; solved; non-target-like

1 SG she's making a .... Pan, panpin [doll (in Basque)], pumpkin?

2 ER no, eso es calabaza [no, that means pumpkin] laughter. ¿Cómo se dice? [how do you say it?]

3 SG muñeco [doll]... and the ....panpin, yo qué sé! [doll ... what do I know!]

$4 \quad$ ER then, panpin, eh?

As for the statistical analysis of the data, both descriptive and inferential statistical procedures were conducted. In the case of descriptive analyses, the number of LREs, the number of LRE types as well as their percentages, mean scores, and standard deviations were calculated. Regarding inferential analyses, since the data did not follow a normal distribution for most of the variables examined, non-parametric tests were computed. Between-group comparisons were analysed using the Kruskal Wallis and Mann-Whitney U tests, while Friedman and Wilcoxon Signed Rank tests were used for within-group comparisons. Statistical probability values were marked at below 0.05 for significant differences and below.09 for marginal differences ${ }^{4}$.

\section{Results}

In this section we will show the results of the analyses computed to answer the two research questions 5 . First, the analyses for the intergroup comparisons (research question 1) will be shown. Table 2 illustrates the results for incidence and nature of LREs:

4 Given the lack of studies targeting young learners along these lines, marginal differences could potentially uncover tendencies that could be further examined in a larger sample.

5 Note that as in other studies conducted within the very same project, 5 th and 6 th year learners have been examined jointly as their proficiency scores were in the range A1-A2 (beginner level). This decision aligns with previous research targeting young learners in which proficiency did not play a major role when comparing 5th and 6th year learners due to the small gap in terms of proficiency between the years tested (i.e. Gallardo-del-Puerto, Basterrechea, \& Martínez-Adrián, 2020). If a wider gap in proficiency had been attested between grades (as suggested by these previous investigations), we would have explored and discussed the effect of different proficiency levels. 
Table 2. Number, percentages, means and standard deviations of LREs initiated by same- and mixed-gender dyads

\begin{tabular}{lll}
\hline & Same-gender dyads & Mixed-gender dyads \\
\hline Incidence & Number 98 & Number 11 \\
& Mean 4.67 & Mean 1.57 \\
& Standard Deviation 3.10 & Standard Deviation 1.51 \\
\hline Nature of LREs & & \\
\hline Meaning-related & Number 91 & Number 11 \\
& Percentage 92.86\% & Percentage 100\% \\
& Mean 4.33 & Mean 1.57 \\
& Standard Deviation 2.90 & Standard Deviation 1.51 \\
\hline \multirow{2}{*}{ Form-related } & Number 7 & Number 0 \\
& Percentage 7.14\% & Percentage 0 \\
& Mean 0.33 & Mean 0 \\
& Standard Deviation 0.79 & Standard Deviation 0 \\
\hline
\end{tabular}

The results (Table 2) revealed that same-gender dyads produced more LREs than mixed-gender dyads $(\mathrm{Z}=-2.324, \mathrm{p}=0.020)$. As for nature, most LREs were meaningrelated in both types of dyads but same-gender dyads significantly produced more $(\mathrm{Z}=-2.244, \mathrm{p}=0.025)$.

Details of the outcome of the LREs are shown in Table 3: 
Table 3. Number, percentages, means and standard deviations of outcomes of LREs initiated by same- and mixed-gender dyads

\begin{tabular}{|c|c|c|}
\hline & Same-gender dyads & Mixed-gender dyads \\
\hline \multicolumn{3}{|l|}{ Meaning-related } \\
\hline Resolved & $\begin{array}{l}\text { Number } 71 \\
\text { Percentage } 78.02 \% \\
\text { Mean 3.38 } \\
\text { Standard Deviation } 2.57\end{array}$ & $\begin{array}{l}\text { Number } 7 \\
\text { Percentage 63,64\% } \\
\text { Mean } 1.00 \\
\text { Standard Deviation } 1.41\end{array}$ \\
\hline Target-like & $\begin{array}{l}\text { Number } 33 \\
\text { Percentage } 46.48 \% \\
\text { Mean } 1.57 \\
\text { Standard Deviation } 1.59\end{array}$ & $\begin{array}{l}\text { Number } 3 \\
\text { Percentage } 42.86 \% \\
\text { Mean } 0.43 \\
\text { Standard Deviation } 0.78\end{array}$ \\
\hline Non-target-like & $\begin{array}{l}\text { Number } 38 \\
\text { Percentage } 53.52 \% \\
\text { Mean } 1.81 \\
\text { Standard Deviation } 1.99\end{array}$ & $\begin{array}{l}\text { Number } 4 \\
\text { Percentage } 57.14 \% \\
\text { Mean 0.57 } \\
\text { Standard Deviation } 0.78\end{array}$ \\
\hline Unresolved & $\begin{array}{l}\text { Number } 20 \\
\text { Percentage } 21.98 \% \\
\text { Mean 0.95 } \\
\text { Standard Deviation } 1.07\end{array}$ & $\begin{array}{l}\text { Number } 4 \\
\text { Percentage } 36.36 \% \\
\text { Mean 0.57 } \\
\text { Standard Deviation } 0.97\end{array}$ \\
\hline \multicolumn{3}{|l|}{ Form-related } \\
\hline Resolved & $\begin{array}{l}\text { Number } 7 \\
\text { Percentage 100\% } \\
\text { Mean 0.33 } \\
\text { Standard Deviation } 0.79\end{array}$ & $\begin{array}{l}\text { Number } 0 \\
\text { Percentage } 0 \\
\text { Mean 0 } \\
\text { Standard Deviation } 0 \\
\end{array}$ \\
\hline Target-like & $\begin{array}{l}\text { Number } 5 \\
\text { Percentage } 71.43 \% \\
\text { Mean 0.24 } \\
\text { Standard Deviation } 0.7\end{array}$ & $\begin{array}{l}\text { Number } 0 \\
\text { Percentage } 0 \\
\text { Mean 0 } \\
\text { Standard Deviation } 0\end{array}$ \\
\hline Non-target-like & $\begin{array}{l}\text { Number } 2 \\
\text { Percentage 28.57\% } \\
\text { Mean 0.10 } \\
\text { Standard Deviation } 0.43\end{array}$ & $\begin{array}{l}\text { Number } 0 \\
\text { Percentage } 0 \\
\text { Mean 0 } \\
\text { Standard Deviation } 0\end{array}$ \\
\hline Unresolved & $\begin{array}{l}\text { Number } 0 \\
\text { Percentage } 0 \\
\text { Mean 0 } \\
\text { Standard Deviation } 0\end{array}$ & $\begin{array}{l}\text { Number } 0 \\
\text { Percentage } 0 \\
\text { Mean 0 } \\
\text { Standard Deviation } 0\end{array}$ \\
\hline
\end{tabular}

The results showed that same-gender dyads resolved meaning-related LREs more frequently $(\mathrm{Z}=-2.261, \mathrm{p}=0.024)$ and that their resolution was more often target-like $(\mathrm{Z}=$ 2.051, $\mathrm{p}=0.040$ ) than mixed-gender dyads. With respect to LREs resolved in a non-targetlike manner and the number of unresolved meaning LREs, no differences were found. As regards form-related LREs, no differences were found between the two groups. 
A second set of analyses to answer the first research question was carried out comparing MM, FF and mixed-gender dyads as regards incidence, nature and outcome of LREs (Table 4).

Table 4. Number, percentages, means and standard deviations of number, type and outcomes of LREs initiated by MM, FF and mixed-gender dyads

\begin{tabular}{|c|c|c|c|}
\hline & \multicolumn{2}{|c|}{ Same-gender dyads } & \multirow[t]{2}{*}{ Mixed-gender dyads } \\
\hline & $\mathrm{MM}$ & $\mathrm{FF}$ & \\
\hline No of LREs & $\begin{array}{l}\text { Number } 66 \\
\text { Mean } 4.40 \\
\text { Standard Deviation } 3.13\end{array}$ & $\begin{array}{l}\text { Number } 32 \\
\text { Mean } 5.33 \\
\text { Standard Deviation } 3.20\end{array}$ & $\begin{array}{l}\text { Number } 11 \\
\text { Mean } 1.57 \\
\text { Standard Deviation } 1.51\end{array}$ \\
\hline $\begin{array}{l}\text { Meaning- } \\
\text { related }\end{array}$ & $\begin{array}{l}\text { Number } 59 \\
\text { Percentage } 89.39 \% \\
\text { Mean } 3.93 \\
\text { Standard Deviation } 2.78\end{array}$ & $\begin{array}{l}\text { Number } 32 \\
\text { Percentage } 100 \% \\
\text { Mean } 5.33 \\
\text { Standard Deviation } 3.20\end{array}$ & $\begin{array}{l}\text { Number } 11 \\
\text { Percentage } 100 \% \\
\text { Mean } 1.57 \\
\text { Standard Deviation } 1.51\end{array}$ \\
\hline Resolved & $\begin{array}{l}\text { Number } 46 \\
\text { Percentage } 77.97 \% \\
\text { Mean } 3.07 \\
\text { Standard Deviation } 2.52\end{array}$ & $\begin{array}{l}\text { Number } 25 \\
\text { Percentage } 78.13 \% \\
\text { Mean } 4.17 \\
\text { Standard Deviation } 2.78\end{array}$ & $\begin{array}{l}\text { Number } 7 \\
\text { Percentage } 63.64 \% \\
\text { Mean } 1 \\
\text { Standard Deviation } 1.41\end{array}$ \\
\hline Target-like & $\begin{array}{l}\text { Number } 18 \\
\text { Percentage } 39.13 \% \\
\text { Mean } 1.20 \\
\text { Standard Deviation } 1.26\end{array}$ & $\begin{array}{l}\text { Number } 15 \\
\text { Percentage } 60 \% \\
\text { Mean } 2.50 \text { Standard } \\
\text { Deviation } 2.07\end{array}$ & $\begin{array}{l}\text { Number } 3 \\
\text { Percentage } 42.86 \% \\
\text { Mean } 0.43 \\
\text { Standard Deviation } 0.78\end{array}$ \\
\hline $\begin{array}{l}\text { Non-target- } \\
\text { like }\end{array}$ & $\begin{array}{l}\text { Number } 28 \\
\text { - Percentage } 60.87 \% \\
\text { Mean } 1.87 \\
\text { Standard Deviation } 2.03\end{array}$ & $\begin{array}{l}\text { Number } 10 \\
\text { Percentage } 40 \% \\
\text { Mean } 1.67 \\
\text { Standard Deviation } 2.06\end{array}$ & $\begin{array}{l}\text { Number } 4 \\
\text { Percentage } 57.14 \% \\
\text { Mean } 0.57 \\
\text { Standard Deviation } 0.78\end{array}$ \\
\hline Unresolved & $\begin{array}{l}\text { Number } 13 \\
\text { Percentage } 22.03 \% \\
\text { Mean } 0.87 \\
\text { Standard Deviation } 1.18\end{array}$ & $\begin{array}{l}\text { Number } 7 \\
\text { Percentage } 21.87 \% \\
\text { Mean } 1.17 \\
\text { Standard Deviation } 0.75\end{array}$ & $\begin{array}{l}\text { Number } 4 \\
\text { Percentage } 36.36 \% \\
\text { Mean } 0.57 \\
\text { Standard Deviation } 0.97\end{array}$ \\
\hline Form-related & $\begin{array}{l}\text { Number } 7 \\
\text { Percentage } 10.61 \% \\
\text { Mean } 0.47 \\
\text { Standard Deviation } 0.91\end{array}$ & $\begin{array}{l}\text { Number } 0 \\
\text { Percentage } 0 \\
\text { Mean } 0 \\
\text { Standard Deviation } 0\end{array}$ & $\begin{array}{l}\text { Number } 0 \\
\text { Percentage } 0 \\
\text { Mean } 0 \\
\text { Standard Deviation } 0\end{array}$ \\
\hline Resolved & $\begin{array}{l}\text { Number } 7 \\
\text { Percentage } 100 \% \\
\text { Mean } 0.47 \\
\text { Standard Deviation } 0.91\end{array}$ & $\begin{array}{l}\text { Number } 0 \\
\text { Percentage } 0 \\
\text { Mean } 0 \\
\text { Standard Deviation } 0\end{array}$ & $\begin{array}{l}\text { Number } 0 \\
\text { Percentage } 0 \\
\text { Mean } 0 \\
\text { Standard Deviation } 0\end{array}$ \\
\hline
\end{tabular}




\begin{tabular}{|c|c|c|c|}
\hline Target-like & $\begin{array}{l}\text { Number } 5 \\
\text { Percentage } 71.43 \% \\
\text { Mean } 0.33 \\
\text { Standard Deviation } 0.81\end{array}$ & $\begin{array}{l}\text { Number } 0 \\
\text { Percentage } 0 \\
\text { Mean } 0 \\
\text { Standard Deviation } 0\end{array}$ & $\begin{array}{l}\text { Number } 0 \\
\text { Percentage } 0 \\
\text { Mean } 0 \\
\text { Standard Deviation } 0\end{array}$ \\
\hline $\begin{array}{l}\text { Non-target- } \\
\text { like }\end{array}$ & $\begin{array}{l}\text { Number } 2 \\
\text { - Percentage } 28.57 \% \\
\text { Mean } 0.13 \\
\text { Standard Deviation } 0.52\end{array}$ & $\begin{array}{l}\text { Number } 0 \\
\text { Percentage } 0 \\
\text { Mean } 0 \\
\text { Standard Deviation } 0\end{array}$ & $\begin{array}{l}\text { Number } 0 \\
\text { Percentage } 0 \\
\text { Mean } 0 \\
\text { Standard Deviation } 0\end{array}$ \\
\hline Unresolved & $\begin{array}{l}\text { Number } 0 \\
\text { Percentage } 0 \\
\text { Mean } 0 \\
\text { Standard Deviation } 0\end{array}$ & $\begin{array}{l}\text { Number } 0 \\
\text { Percentage } 0 \\
\text { Mean } 0 \\
\text { Standard Deviation } 0\end{array}$ & $\begin{array}{l}\text { Number } 0 \\
\text { Percentage } 0 \\
\text { Mean } 0 \\
\text { Standard Deviation } 0\end{array}$ \\
\hline
\end{tabular}

The non-parametric Kruskal Wallis statistical analysis revealed marginally significant differences among the three gender pairings in the total number of LREs $\left(X^{2}=5.722\right.$, $\mathrm{p}=0.057)$ and the total number of meaning related LREs $\left(\mathrm{X}^{2}=5.773, \mathrm{p}=0.056\right)$ and a statistically significant difference in the number of target-like resolved meaning related LREs $\left(X^{2}=6.361, p=0.042\right)$. However, these differences emerged only when comparing mixed-gender dyads with the MM and the FF dyads but not between same-gender dyads. Note that although it was the case that all form-related LREs were produced by MM dyads, the statistical analysis did not reveal a difference when compared to the production of form-related LREs by the FF dyads. Mixed-gender dyads produced fewer LREs than MM ( $Z=-2.066, p=0.039)$ and FF dyads $(Z=-2.089, p=0.037)$; fewer meaning-related LREs than MM $(Z=-1.957, p=0.050)$ and $F F(Z=-2.089, p=0.037)$ dyads; fewer resolved meaning-related LREs than MM $(Z=-2.058$, $p=0.040)$ and $F F(Z=-1.970$, $\mathrm{p}=0.049)$ dyads; and fewer target-like resolved meaning-related LREs than FF dyads ( $Z=-$ 2.189, $\mathrm{p}=0.029$ ).

To answer the second research question, within-group analyses were carried out for each dyad type (MM, FF and mixed-gender pairings). Within group comparisons indicated there were differences within $\mathrm{MM}\left(\mathrm{X}^{2}=84.545, \mathrm{p}=0.000\right), \mathrm{FF}\left(\mathrm{X}^{2}=41.020, \mathrm{p}=0.000\right)$ and mixed-gender dyads $\left(X^{2}=29.172, p=0.001\right)$. All three types of dyads produced more meaning-related LREs than form-related LREs (MM ( $\mathrm{Z}=-3.320$, $\mathrm{p}=0.001), \mathrm{FF}(\mathrm{Z}=-2.023$, $\mathrm{p}=0.043)$ and mixed-gender $(\mathrm{Z}=-2.032, \mathrm{p}=0.042))$. However, while further differences were observed between meaning and form LREs in both same-gender dyads, no such differences emerged in the mixed-gender dyads. More specifically, MM dyads produced more resolved than unresolved meaning-related LREs $(\mathrm{Z}=-2.528, \mathrm{p}=0.011)$ and marginally they also produced more resolved than unresolved form-related LREs ( $Z=$ 1.841, $\mathrm{p}=0.066$ ). Nevertheless, the number of meaning- and form-related LREs resolved in a target-like manner did not significantly differ from those resolved in a non-target- 
like manner. When comparing the number of target-like resolved form with target-like meaning LREs, a marginally significant difference emerged in favour of meaning-related LREs ( $\mathrm{Z}=1.910, \mathrm{p}=0.056)$. The comparison between meaning- and form-related LREs as regards non-target-like episodes also yielded a statistically significant difference in favour of meaning-related LREs $(z=-2.816, p=0.005)$. Within the FF dyads, the analysis showed a significantly higher mean of resolved over unresolved meaning-related LREs $(\mathrm{Z}=-2.032, \mathrm{p}=0.042)$. Similarly, in FF dyads the contrast between target-like resolved and non-target-like resolved LREs did not reach statistical significance.

\section{Discussion}

The first research question focused on the existence of any differences among MM, FF and mixed-gender dyads in the number, types and outcomes of LREs produced by 10-12-year-old children. The results revealed that same-gender pairings produced a significantly higher number of LREs and resolved LREs than mixed-gender dyads. This seems to show that children as young as 10-12 benefit from working in same-gender dyads more than in mixed-gender dyads. This result has also been reported for L1 (Fabes, Martin, \& Hanish, 2003) and L2 children (Azkarai \& Imaz Agirre, 2017) but not in those studies that have investigated LRE production with adult L2 learners. In this sense, Azkarai (2015b), Azkarai and García Mayo (2012) and Ross-Feldman (2005, 2007) reported no differences in the occurrence and nature of LREs between mixed-and samegender dyads during interaction among adults. However, when it comes to resolution of LREs, Azkarai (2015b: 25) reported that mixed-gender dyads had more opportunities to resolve LREs than same-gender dyads, perhaps "because males seemed to be more decisive than females during interactive work”. Additionally, Ross-Feldman $(2005,2007)$ also reported a difference in resolution in that mixed-gender dyads were more favourable for males while same-gender dyads seemed to be more beneficial for females.

As regards the outcome of the resolution of LREs (i.e. whether the LREs were resolved in a target-like or in a non-target-like way), the rate of target-like resolutions was always below 50\% in the three pairings (MM: 30.51\%, FF: $46.88 \%$ and Mixed: $27.27 \%$ ) despite having been asked to focus on accuracy in the instructions provided. In other words, the inherent focus of the task overruled the framing of the task (Philp, Walter, \& Basturkmen, 2010). As reported in previous studies with adults (Adams, 2006; Adams \& Ross-Feldman, 2008; García Mayo \& Azkarai, 2016; Niu, 2009; Payant $\&$ Kim, 2019), oral tasks are more immediate and offer more communicative pressure to the learner, which may limit opportunities for greater accuracy. However, unlike adults and adolescents from previous investigations (Lasito \& Storch, 2013; Niu, 2009), children from the present investigation showed even more difficulties in rapidly retrieving and verbalizing their explicit knowledge which could lead them to solve 
their gaps in a more target-like way. This might indicate that negotiating successfully is a skill that needs a longer time to develop in young learners (see Gallardo-del-Puerto \& Martínez-Adrián, in press in this respect).

The examination of the results also revealed a higher number of target-like resolved LREs in FF dyads than in mixed-gender dyads but no differences between mixedgender and MM dyads. Even if the rate of target-like resolutions for meaning-related LREs is always below 50\% in the three pairings (MM: 30.51\%, FF: $46.88 \%$ and Mixed: $27.27 \%$ ), a slight advantage is observed on the part of $\mathrm{FF}$ over mixed-gender pairings. In fact, the examination of the descriptive means shows that target-like resolutions are more common than non-target-like episodes in the FF dyads, while the opposite trend is obtained in the MM and mixed-gender pairings, a result which will also be discussed in connection to the second research question.

Moreover, the between-group analysis indicated the inexistence of statistically significant differences between MM and FF dyads in incidence, nature and resolution of LREs. Thus, there is little impact of the variable 'gender' as also reported in Azkarai and Imaz Agirre (2017) with EFL children and Oliver (2002) with ESL children and Azkarai (2015b) with EFL adults. However, the results partially support Ross-Feldman $(2005,2007)$ who found no differences in incidence but in resolution as more resolved LREs were attested in the adult male learners examined in her sample.

With respect to the second research question which inquired into the type of LREs (nature and outcome) which are more common in each dyad group, the analysis indicated that in the three dyad groups, and as regards the nature of LREs, learners significantly produced more meaning-related than form-related LREs. The task administered, an oral task, is a communication-oriented task with an inherent immediate nature, and to satisfy its demands, these young learners are in the need of key vocabulary to move it forward (García Mayo \& Azkarai, 2016; García Mayo \& Imaz Agirre, 2019; Payant \& Kim, 2019; Swain \& Watanabe, 2013). This contrasts with tasks that offer the learners more time to think and to reflect on their production, where young learners have been found to focus both on meaning and form (Gallardo-del-Puerto \& Martínez-Adrián, in press; García Mayo \& Imaz Agirre, 2019). Notwithstanding, it is worth mentioning that only malemale pairings were found to produce form-related LREs in addition to meaning-focused LREs in this oral task. We could tentatively argue that males discuss a wider range of issues not just limited to lexis, whereas females are more concerned with conveying the message in a task whose primary focus is meaning. In this vein, this finding aligns with prior L1 research, where males have been reported to discuss many topics briefly in 
matched-gender dyads (Tannen, 1990) ${ }^{6}$. In addition, other investigations on the use of communication strategies with same-age learners have also revealed how girls report being less risky than boys when communicating, which shows a strong preference for efficiency so as to get their message across without communication breakdowns (see Basterrechea, Martínez-Adrián, \& Gallardo-del-Puerto, 2017).

In terms of resolution, the finding that young male and female learners produce more resolved than unresolved LREs in matched-gender dyads may indicate that children generate more opportunities to learn when working in same-gender dyads. This result aligns with $\mathrm{L} 1$ acquisition studies according to which same-gender peer preferences in children become stronger over time (Hanish \& Fabes, 2014). Hanish and Fabes (2014) suggest that the preference for same-gender dyads leads to fewer opportunities for malefemale interaction and hence, fewer opportunities for males and females to learn from each other. This observation is reflected in our study in that mixed-gender dyads are not as effective as same-gender dyads when it comes to resolving LREs.

But even if resolved LREs were significantly higher than unresolved LREs in matched-gender pairings, there was a low rate of target-like resolved LREs (30.51\% in $\mathrm{MM}$ and $46.88 \%$ in FF). In addition to the low rate of target-like resolution in MM and FF dyads, it is also important to highlight the fact that although the difference between both dyads did not reach statistical significance, we can observe a higher mean number of target-like episodes over non-target-like ones in FF dyads, whereas in MM non-target-like episodes outnumber target-like resolutions. This finding might tentatively indicate that FF dyads could be more oriented to upsurge the correctness of their language discussion outcomes in a task that demands lower levels of accuracy. In this regard, it seems as if these FF dyads conform to the instructions provided to focus on accuracy to a higher extent than boys, a finding which seems to be in line with research in education (see girls' advantage in terms of the social and behavioural skills that are valuable in producing higher levels of academic performance (DiPrete \& Buchman, 2013)).

6 This idea seems to be reinforced in that these very same learners (either in male-male or female-female dyads), when tested in another study in which they were asked to perform a speaking ${ }^{+}$writing task that seems to me more powerful in increasing learners' attention to formal issues (see Gallardo-delPuerto \& Martínez-Adrián, in press), were found to produce form-related episodes. So, in the light of these findings, we cannot argue that males are more oriented to form (i.e. grammar, pronunciation issues). Nevertheless, we will have to await other studies that analyse a wider range of tasks to confirm this trend. 


\section{Conclusion}

This study has revealed that type of pairing affects LRE production and resolution as more LREs were initiated and resolved in matched-gender dyads than in mixedgender dyads. However, gender-pairing did not have an impact on the outcome of the resolution, as a still low rate of targetlikeness was obtained in mixed- and matchedgender young dyads. In addition, gender was not a discriminating factor when comparing same-gender dyads, even though FF dyads seem to be more concerned with getting the message across and more oriented to higher accuracy in the resolutions of meaning-related episodes as the descriptive means evinced, findings which need to be confirmed in further studies with larger samples of young learners and a more balanced distribution of dyad types.

In the light of the results, two main pedagogical implications may be drawn for the EFL class. Younger learners may benefit more from working in matchedgender dyads than in mixed-gender dyads, at least in this type of communicative tasks that enhance collaborative dialogue. Second, the inclusion of these oral tasks in the curriculum promotes language focus for young learners and in particular the collaborative construction of meaning. But despite the potential of the adoption of these oral tasks in the curriculum for negotiation of meaning, learning opportunities for young learners should be maximized in this task by the implementation of measures aimed at increasing the accuracy resolution rate. In this respect, ventures already tested with the same learners such as the possibility of edition of their oral production in a similar task as the one employed in the present study have been found to promote more target-like resolutions of meaning-related episodes (Gutiérrez-Mangado \& Basterrechea, forthcoming; Martínez-Adrián \& Gallardo-del-Puerto, forthcoming). Likewise, other task options and modalities should be considered to boost accuracy (see Martínez-Adrián, Gutiérrez-Mangado, Gallardo-del-Puerto, \& Basterrechea, in press). In this regard, the incorporation of focused tasks accompanied by appropriate training conditions could enhance metalinguistic awareness, facilitate a greater noticing of gaps and in turn, a better development of language accuracy (Bouffard \& Sarkar, 2008; Shak $\&$ Gardner, 2008).

For future research, taking into account that these results cannot be fully generalizable to other contexts, it would be desirable to conduct this type of research in other cultural settings, as cultural norms have been found to interact with other social factors such as gender. In addition, a wider range of tasks and modalities, as well as the degree of elaboration of LREs (Niu, 2009) should be explored. By investigating more and less focused tasks in which writing components are added that usually lead to greater noticing of grammar features as well as oral tasks in which learners are offered the possibility of editing their production, we will be able to look into whether 
similar trends reported in this study as regards gender-pairings are obtained. Thus, research on the interplay between gender-pairing and task-modality is clearly advocated so as "to inform policy makers and maximise children's opportunities for learning" (García Mayo, 2017: xv). Likewise, the administration of tailor-made posttests could contribute to the study of collaborative dialogue on language development. Similarly, (pseudo)longitudinal studies could also shed more light on the provision of learning opportunities for young learners throughout time. In this respect, we will be able to delve into whether the better performance observed in matched-gender dyads persists during these school years.

\section{Acknowledgements}

The authors would like to acknowledge the grants awarded by the Spanish Ministry of Economy and Competitiveness (FFI2016-74950-P) (AEI/FEDER/UE) and the Basque Government (IT904-16). The authors are also grateful to the school, the teachers and students for their collaboration in the research project.

\section{References}

Adams, R. (2006). L2 tasks and orientation to form: A role for modality? ITL International Journal of Applied Linguistics, 152, 7-34.

Adams, R., \& Ross-Feldman, L. (2008). Does writing influence learner attention to form? In D. Belcher \& A. Hirvela (Eds.), The Oral-literate Connection. Perspectives on L2 Speaking, Writing, and other Media Interactions. (pp. 243-265). Ann Arbor, MI: The University of Michigan Press.

Alcón, E. (1994). The role of participation and gender in non-native speakers' classroom interaction. Working Papers on Language, Gender, and Sexism, 4(1), 51-68.

Alcón, E., \& Codina, V. (1996). The impact of gender on negotiation and vocabulary learning in a situation of interaction. International Journal of Psycholinguistics, 12, 21-35.

Aries, E.J. (1976). Interaction patterns and themes of male, female, and mixed groups. Small Group Behaviour, 7(1), 7-18.

Azkarai, A. (2013). Gender and task-modality in EFL task-based interaction. Unpublished PhD thesis., The University of the Basque Country.

Azkarai, A. (2015a). L1 use in EFL task-based interaction: a matter of gender? European Journal of Applied Linguistics, 3(2), 159-179. 
Azkarai, A. (2015b). Males and females in EFL task-based interaction: does gender have an impact on LREs? Vigo International Journal of Applied Linguistics, 12, 9-35.

Azkarai, A., \& Imaz Agirre, A. (2017). Gender and age in child interaction in an EFL CLIL context: An exploratory study. In M. P. García Mayo (Ed.), Learning Foreign Languages in Primary School: Research Insights. (pp. 103-123). Clevedon, UK: Multilingual Matters.

Azkarai, A., \& García Mayo, M. P. (2012). Does gender influence task performance in EFL? Interactive tasks and language related episodes. In E. Alcón \& M. P. Safont Jordá (Eds.), Language Learners' Discourse across L2 Instructional Settings. (pp. 249-278) Amsterdam: Rodopi.

Azkarai, A., \& García Mayo, M. P. (2015). Task modality and L1 use in EFL oral interaction. Language Teaching Research, 19, 550-571.

Basterrechea, M., Martínez-Adrián, M., \& Gallardo-del-Puerto, F. (2017). Gender effects on strategic competence: A survey study on compensatory strategies in a CLIL context. Estudios de Lingüistica Aplicada (ELIA), 17, 47-70.

Birjandi, P., \& Tabatabaei, O. (2010). Examining the impact of gender on taskbased conversational interactions among EFL learners: The case of recasts. Curriculum Planning, Knowledge and Research in Educational Sciences, 7(26), 35-64.

Bohn, E., \& Stutman, R. (1983). Sex-role differences in the relational control dimension of dyadic interaction. Women's Studies in Communication, 6, 96-104.

Bouffard, L. A., \& Sarkar, M. (2008). Training 8-year-old French immersion students in metalinguistic analysis: An innovation in form-focused pedagogy. Language Awareness, 17(1), 3-24.

Cenoz, J. (2009). Towards Multilingual Education: Basque Educational Research from an International Perspective. Bristol: Multilingual Matters.

DiPrete, T. A., \& Buchman, C. (2013). The Rise of Women. The Growing Gender Gapa in Education and What it Means for American Schools. New York: Russell Stage Foundation.

Fabes, R. A., Martin, C. L., \& Hanish, L. D. (2003). Young children's play qualities in same-, other-, and mixed-sex peer groups. Child Development, 74, 921-932.

Gallardo-del-Puerto, F., \& Martínez-Adrián, M. (In press). Task modality effects on young learners' language related episodes in collaborative dialogue. RESLA.

Gallardo-del-Puerto, F., Basterrechea, M., \& Martínez-Adrián, M. (2020). Target language proficiency and reported use of compensatory strategies by young CLIL learners. International Journal of Applied Linguistics, 30, 3-18. 
García Mayo, M. P. (2017). Introduction. In M. P. García Mayo (Ed.), Learning Foreign Languages in Primary School. (pp. xiii-xxiii). Bristol: Multilingual Matters.

García Mayo, M. P., \& Azkarai, A. (2016). EFL task-based interaction: Does task modality impact on language-related episodes? In M. Sato \& S. Ballinger (eds) Peer Interaction and Second Language Learning: Research Agenda and Pedagogical Potential. (pp.241-266). Amsterdam: John Benjamins.

García Mayo, M. P., \& Hidalgo Gordo, M. A. (2017). L1 Use among young EFL mainstream and CLIL learners in task-supported interaction. System, 67, 132-145.

García Mayo, M.P., \& Imaz Agirre, A. (2019). Task modality and pair formation method: Their impact on patterns of interaction and LREs among EFL primary school children. System, 80, 165-175.

García Mayo, M. P., \& Lázaro Ibarrola, A. (2015). Do children negotiate for meaning in task-based interaction? Evidence from CLIL and EFL settings. System, 54, 40-54.

Gass, S. \& Varonis, E. (1986). Sex differences in non-native speaker/nonnative speaker interactions. In R.R. Day (Eds.), "Talking to Learn": Conversation in Second Language Acquisition. (pp.327-351). Cambridge, MA: Newbury House.

Gu, L. (2013). Language and gender: differences and similarities. Proceedings of the International Conference on Advances in Social Science, Humanities, and Management (ASSHM-13), 248-251.

Gutiérrez-Mangado, M. J., \& Basterrechea, M. (forthcoming). Investigating the effect of task modality on the production of LREs by young learners.

Hanish, L. D., \& Fabes, R. A. (2014). Peer socialization of gender in young boys and girls. Encyclopedia on Early Childhood Development. Montreal, Quebec: Centre of Excellence for Early Childhood Development and Strategic Knowledge Cluster on Early Child Development, 1-4. http://www.child-encyclopedia.com/sites/default/files/textesexperts/en/2492/peer-socialization-of-gender-in-young-boys-and-girls.pdf

Holmes, J. (1994). Improving the lot of female language learners. In J. Sunderland (ed) Exploring Gender: Questions and implication of English Language Education., (pp. 156162). London: Prentice Hall.

House, S., \& Scott, K. (2009). Sparks 1. London: Richmond.

Lasito, \& Storch, N. (2013). Comparing pair and small group interactions on oral tasks. RELC Journal, 44, 361-375.

Lázaro Ibarrola, A., \& Azpilicueta Martínez, R. (2015). Investigating negotiation of meaning in EFL children with very low levels of proficiency. International Journal of English Studies, 15, 1-21. 
Long, M. (1996). The role of the linguistic environment in second language acquisition. In W. C. Ritchie \& T. K. Bhatia (eds) Handbook of Second Language Acquisition. (pp. 413-468). San Diego, CA: Academic Press.

Maltz, D. N., \& Borker, R. A. (1982). A cultural approach to male-female miscommunication. In J. Gumperz (Eds.), Language and Identity. (pp.195-216). Cambridge: Cambridge University Press.

Martínez-Adrián, M. (2020). ¿Los juntamos? A study of L1 use in interactional strategies in CLIL vs. non-CLIL primary school learners. International Review of Applied Linguistics in Language Teaching (IRAL), 58(1), 1-27.

Martínez-Adrián, M., \& Gallardo-del-Puerto, F. (forthcoming). Task modality: The control of accuracy and edition in output.

Martínez-Adrián, M., Gutiérrez-Mangado, M. J., Gallardo-del-Puerto, F., \& Basterrechea, M. (In press). Language-related episodes by young CLIL learners: A review of task modality effects. Language Teaching for Young Learners.

McWhinney, B. (2000). The CHILDES Project: Tools for Analyzing Talk (3rd ed.). Mahwah, NJ: Lawrence Erlbaum.

Mehta, C. M., \& Strough, J. (2009). Sex segregation in friendships and normative contexts across the life span. Developmental Review, 29, 201-220.

Mehta, C. M., \& Strough, J. (2010). Gender segregation and gender-typing in adolescence. Sex Roles, 63, 251-263.

Niu, R. (2009). Effect of task-inherent production modes on EFL learners' focus on form. Language Awareness, 18 (3-4), 384-402.

Oliver, R. (2002). The patterns of negotiation for meaning in child interactions. The Modern Language Journal, 86(1), 97-111.

Oliver, R., \& Azkarai, A. (2017). Review of child second language acquisition (SLA): Examining theories and research. Annual Review of Applied Linguistics, 37, $62-76$.

Pavlenko, A. (2001). "How am I to become a woman in an American vein?": Negotiation of gender in second language learning. In A. Pavlenko, A. Blackledge, I. Piller, \& M. Teutsch-Dwyer (Eds.), Second Language Learning, Multilingualism, and Gender. (pp. 133-174). Berlin: Mouton De Gruyter.

Pavlenko, A., \& Piller, I. (2008). Language education and gender. In S. May \& N. H. Hornberger (Eds.), Encyclopedia of Language and Education. (pp. 57-69). New York: Springer Science+Business Media LLC.

Payant, C., \& Kim, Y. J. (2019). Impact of task modality on collaborative dialogue among plurilingual learners: a classroom-based study. International Journal of Bilingual Education and Bilingualism, 22(5), 614-627. 
Philp, J., Walter, S., \& Basturkmen, H. (2010). Peer interaction in the foreign language classroom: What factors foster a focus on form? Language Awareness, 19(4), 261-279.

Pica, T., Holliday, L., Lewis, N. E., Berducci, D., \& Newman, J. (1991). Language learning through interaction: What role does gender play? Studies in Second Language Acquisition, 13, 343 - 376.

Pica, T., Kanagy, R., \& Falodun, J. (1993). Choosing and using communication tasks for second language instruction and research. In G. Crookes \& S. M. Gass (Eds.), Tasks and Language Learning: Integrating Theory and Practice. (pp. 9-34). Clevedon: Multilingual Matters.

Pica, T., Kang, H., \& Sauro, S. (2006). Information gap tasks: Their multiple roles and contributions to interaction research methodology. Studies in Second Language Acquisition, 28, 301-338.

Pinter, A. (2011). Children Learning Second Languages. Basingstoke, U.K: Palgrave Macmillan.

Pladevall Ballester, E., \& Vraciu, A. (2020). EFL child peer interaction: Measuring the effect of time, proficiency pairing and language of interaction. Studies in Second Language Learning and Teaching, 10(3), 449-472.

Ross-Feldman, L. (2005). Task-based interactions between second language learners: Exploring the role of gender. Unpublished $\mathrm{PhD}$ thesis, Georgetown University.

Ross-Feldman, L. (2007). Interaction in the L2 classroom: Does gender influence learning opportunities? In A. Mackey (Eds.), Conversational Interaction in Second Language Acquisition: A Collection of Empirical Studies. (pp.52-77). Oxford: Oxford University Press.

Sadker, M., \& Sadker, D. (1994). Failing at Fairness: How our Schools Cheat Girls. New York: Simon \& Schuster.

Shak, J., \& Gardner, S. (2008). Young learner perspectives on four focus-on-form tasks. Language Teaching Research, 12(3), 387-408.

Shehadeh, A. (1994). Gender differences and second language acquisition. Research Journal of Aleppo University (Arts and Humanities Series), 26, 73 - 98.

Shehadeh, A. (1999). Gender differences and equal opportunities in the ESL classroom. ELT Journal 53, 256-261.

Spolsky, B. (1989). Conditions for Second Language Learning: Introduction to a General Theory. Oxford: Oxford University Press.

Sunderland, J. (2000). Issues of language and gender in second and foreign language education. Language Teaching, 33(4), 203-223. 
Swain, M. (1998). Focus on form through conscious reflection. In by C. Doughty \& J. Williams (ed) Focus on Form in Classroom Second Language Acquisition. (pp. 64-81). Cambridge: Cambridge University Press.

Swain, M., \& Watanabe, Y. (2013). Languaging: Collaborative dialogue as a source of second language learning. In C. Chapelle (Ed.), The Encyclopedia of Applied Linguistics. Oxford: Wiley-Blackwell.

Tannen, D. (1990). You Just Don't Understand. Women and Men in Conversation. New York: William Morrow.

Tannen, D. (1994). Gender and Discourse. New York: Oxford University Press.

Van Lier, L. (1988). The Classroom and the Language Learner: Ethnography and SecondLanguage Classroom Research. London: Longman.

West, C., \& García, A. (1988). Conversational shift work: A study of topical transitions between women and men. Social Problems, 35(5), 551-575.

West, C., \& Zimmerman, D. (1983). Small insults: A study of interruptions in cross-sex conversations between unacquainted persons. In B. Thorne, C. Kramarae \& N. Henley (Eds.), Language, Gender and Society (pp.102-117). Rowley, Mass: Newbury House.

Zalbide, M., \& Cenoz, J. (2008). Bilingual education in the Basque Autonomous Community: Achievements and challenges. In J. Cenoz (Ed.), Teaching through Basque. (pp.5-20). Clevedon: Multilingual Matters.

Zimmerman, D., \& West, C. (1975). Sex roles, interruptions and silences in conversation. In B. Thorne \& N. Henley (Eds.), Language and Sex: Difference and Dominance. (pp.105-129). Rowley, Mass: Newbury House. 


\section{Appendix 1}
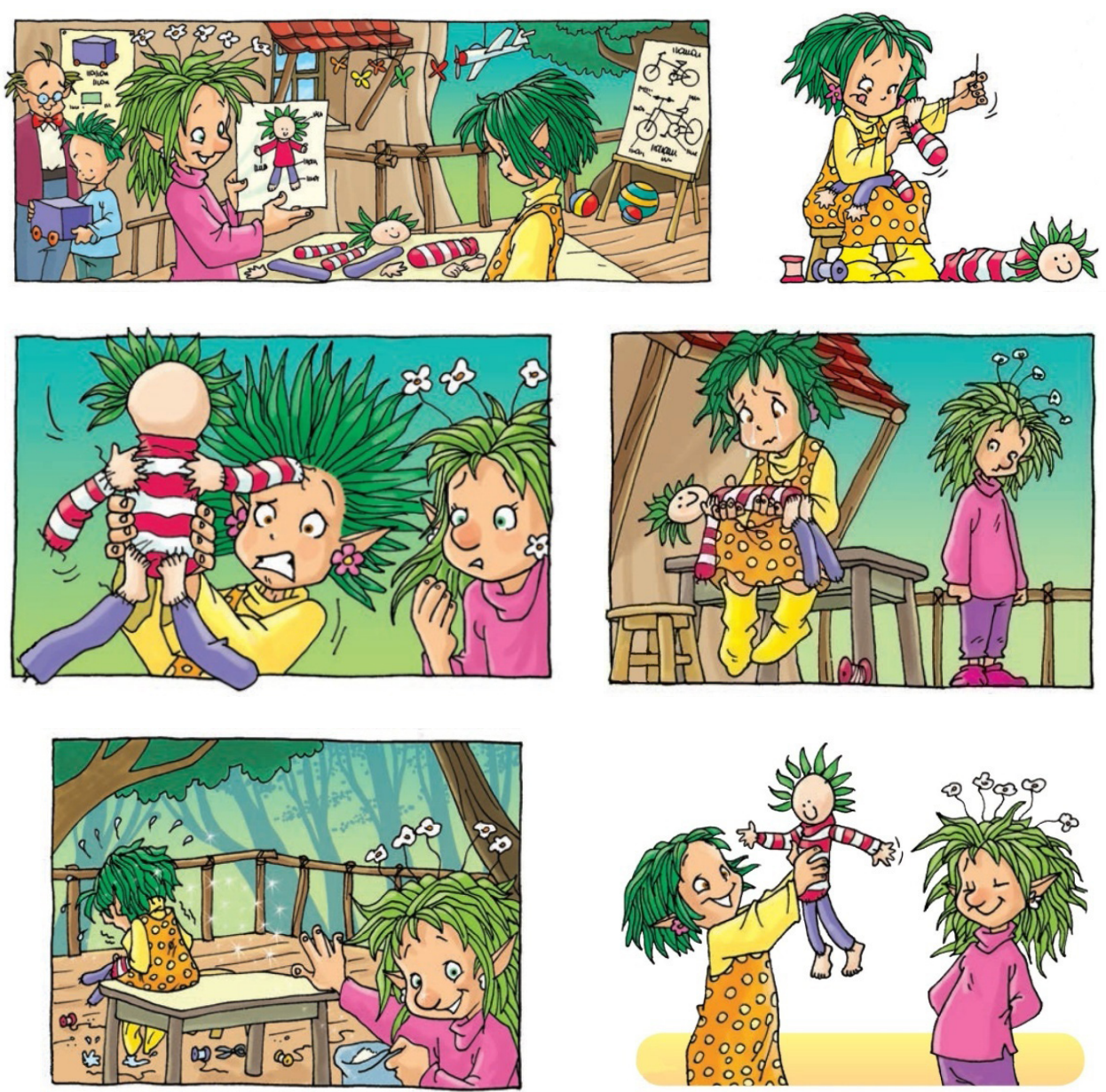

Source: https://www.guiassantillana.com/ingl\%C3\%A9s/sparks/ 